This document is the accepted manuscript version of the following article:

Uh1, A. R., Fuchs, P., Rieger, A., Pianezzi, F., Sutter-Fella, C. M., Kranz, L., ...

Tiwari, A. N. (2015). Liquid-selenium-enhanced grain growth of nanoparticle precursor layers for CuInse2 solar cel1 absorbers. Progress in Photovoltaics, 23(9), 1110-1119. https://doi.org/10.1002/pip.2529

\title{
Progress in Photovoltaics: Research and Applications
}

\section{Liquid-selenium-enhanced grain growth of nanoparticle precursor layers for $\mathrm{CuInSe}_{2}$ solar cell absorbers}

\author{
Alexander R. Uhl ${ }^{1, *}$, Peter Fuchs ${ }^{1}$, Alexandra Rieger ${ }^{1}$, Fabian Pianezzi ${ }^{1}$, Carolin M. Sutter- \\ Fella ${ }^{l}$, Lukas Kranz ${ }^{l}$, Debora Keller ${ }^{l}$, Harald Hagendorfer ${ }^{l}$, Yaroslav E. Romanyuk ${ }^{l}$, \\ Fabio LaMattina ${ }^{2}$, Songhak Yoon ${ }^{3}$, Lassi Karvonen ${ }^{3}$, Theresa Magorian-Friedlmeier ${ }^{4}$, \\ Erik Ahlswede ${ }^{4}$, Dirk VanGenechten ${ }^{5}$, Fabrice Stassin ${ }^{5}$, and Ayodhya N. Tiwari ${ }^{l}$
}

\author{
${ }^{1}$ Laboratory for Thin Films and Photovoltaics, Empa - Swiss Federal Laboratories for Materials Science and \\ Technology, Ueberlandstrasse 129, 8600 Duebendorf, Switzerland \\ ${ }^{2}$ Laboratory for Electronics/ Metrology/ Reliability, Empa - Swiss Federal Laboratories for Materials Science \\ and Technology, Ueberlandstrasse 129, 8600 Duebendorf, Switzerland \\ ${ }^{3}$ Laboratory for Solid State Chemistry and Catalysis, Empa - Swiss Federal Laboratories for Materials Science \\ and Technology, Ueberlandstrasse 129, 8600 Duebendorf, Switzerland \\ ${ }^{4}$ Zentrum für Sonnenenergie und Wasserstoff-Forschung (ZSW), Industriestrasse 6, 70565 Stuttgart, Germany \\ ${ }^{5}$ Umicore S.A., Watertorenstraat 33, 2250 Olen, Belgium \\ *corresponding author: uhl.alexander@gmail.com
}

\section{ABSTRACT}

Large-grained $\mathrm{CuInSe} 2$ absorber layers are synthesized using a non-vacuum process based on nanoparticle ink precursors and selenization by rapid thermal processing (RTP). The use of hydroxide based particles in organic solvents allows for the conversion with elemental selenium without the need to employ explosive and/or toxic $\mathrm{H}_{2}$ or $\mathrm{H}_{2} \mathrm{Se}$ gases. Lateral grain sizes up to $4 \mu \mathrm{m}$ are obtained through a novel RTP route, overcoming the inherently high layer porosity for previous nanoparticle processes. Morphological and elemental characterization at interrupted selenization steps suggests that liquid selenium can play a beneficial role in promoting layer densification and grain growth. Large carrier collection lengths in $\mathrm{CuInSe}_{2}$ enable notable conversion efficiencies up to $8.00 \%$, despite the low minority carrier lifetimes of below 1 ns. Record efficiencies up to $8.73 \%$ highlight the potential of low-cost, non-vacuum deposition of chalcopyrite absorber layers with safe and simple precursors and processing routes.

\section{INTRODUCTION}

Solar cells based on $\mathrm{Cu}$ (In,Ga)Se 2 (CIGS) absorbers exhibit the highest efficiency among all thin film solar cells up to $20.9 \%$ and have gained even more attention recently by exceeding efficiency values of market leading poly-Si solar cells [1,2]. While state-of-the-art deposition of CIGS continues to be carried out by vacuum processes, novel concepts for processes utilizing non-vacuum printing methods have the potential to significantly lower production costs by reducing capital investment, increasing material utilization, and enabling large-area and high-throughput fabrication. Several companies and institutes have already proven the feasibility of this concept by achieving $17.1 \%$ and $15.2 \%$ efficient devices based on printed CIGS layers [3,4]. From the first synthesis of CuInSe 2 in 1953 to the first $10 \%$ cell in 1981, the focus on cell development has mainly shifted away from the $\mathrm{CuInSe}_{2}$ (CIS) material to 
$\mathrm{Cu}(\mathrm{In}, \mathrm{Ga}) \mathrm{Se}_{2}$ due to its larger band gap [5,6]. While CIS devices obtained by vacuum processes display up to $15 \%$ efficiency $[7,8]$, reported values utilizing non-vacuum processes are either considerably lower, i.e. 7.0\% [9], or necessitate the use of highly toxic and explosive hydrazine solvent (8.86\%) [10], or $\mathrm{H}_{2} \mathrm{Se}$ gas $(13 \%)$ [11,12]. Most successful nonvacuum approaches typically employ a direct liquid coating and subsequent conversion step to form a chalcopyrite layer. To avoid carbon contamination from ink residuals, true solutions from carbon free solvents, i.e. $\mathrm{N}_{2} \mathrm{H}_{4}$, or nanoparticle routes without organic coordination of the metal cations are preferred. However, lower molecular intermixing and remaining porosity are evident downsides of the nanoparticle route [13,14]. In that regard, it is imperative to find suitable fluxing agents to ensure metal diffusion and grain growth. Vervaet and Casteleyn et al. investigated multiple fluxing agents to promote $\mathrm{CuInSe} 2$ densification and grain growth, amongst them $\mathrm{Cu}-\mathrm{Se}, \mathrm{CuCl}$, and $\mathrm{Se}$ [15-18]. However, while sintering temperatures between 525 and $650{ }^{\circ} \mathrm{C}$ were employed, the best cell efficiencies remained below $3 \%$.

In this paper, we present the liquid-selenium-assisted growth of mixed $\mathrm{Cu}$ - and Inhydroxide-based nanoparticles that show remarkable lateral grain size of up to $4 \mu \mathrm{m}$ diameter at process temperatures below $500{ }^{\circ} \mathrm{C}$. The weak coordination of hydroxide anions together with the organic solvent butyl glycol acetate (BGA) enabled effective selenization without explosive and/or toxic $\mathrm{H}_{2}$ and $\mathrm{H}_{2} \mathrm{Se}$ gases. Notable efficiencies of up to $8.73 \%$ highlight the potential of this safe and simple processing route.

\section{EXPERIMENTAL DETAILS}

All precursor films were knife-coated and dried in a fume hood in ambient air. Stable $\mathrm{Cu}$ - and In- containing dispersions were initially prepared by processes described in [14]. The solid load in butyl glycol solvent was 20-25 wt.\% while the amount of polymeric dispersant (NUOSPERSE, type FX) ranged between 15 - $20 \mathrm{wt} . \%$ relative to the solids. Using dynamic light scattering method, the mass median diameter (D50) of particles was determined to be between $50-100 \mathrm{~nm}$. Additionally, individual dispersions underwent filtration by $1 \mu \mathrm{m}$ glass-fiber filters prior to mixing them targeting a final stoichiometry of $\mathrm{Cu} / \mathrm{In}=1.05$, as determined by ICP-MS. Films were deposited on a $500 \mathrm{~nm}$ thick Mo- layer on soda-lime glass substrates and consecutively dried on a hotplate at $200{ }^{\circ} \mathrm{C}$ for 3 minutes. By repetition of this process or adjusting the knife-to-substrate distance it was possible to tailor the precursor film thickness. The best films were obtained using a knife-speed of $50 \mathrm{~mm} / \mathrm{s}$, a substrate temperature of $80^{\circ} \mathrm{C}$, and 2 passes with a nominal substrate-to-knife distance of $10 \mu \mathrm{m}$. The precursor layers were then covered by a $3-5 \mu \mathrm{m}$ layer of selenium which was evaporated at $10^{-7}$ mbar by PVD. The total precursor composition was determined to be around 80 at.\% Se through XRF. Samples were then converted by rapid thermal processing in a graphite box at close to atmospheric pressure. IR-radiation from halogen lamps enabled heating rates up to $5{ }^{\circ} \mathrm{C}$ while providing a homogeneous temperature distribution for the annealing of the samples up to $500{ }^{\circ} \mathrm{C}$ with dwell times around 20 minutes.

Solar cell absorbers were treated with a $10 \mathrm{wt} . \% \mathrm{KCN}$ aqueous solution for 1 minute to remove residual $\mathrm{Cu}-\mathrm{Se}$ phases, reducing the $\mathrm{Cu} / \mathrm{In}$ ratio to unity [19]. A $50 \mathrm{~nm}$ thick $\mathrm{CdS}$ 
layer was then deposited using chemical bath method. Solar cells were finalized by RFsputtering of an $\mathrm{i}-\mathrm{ZnO} / \mathrm{ZnO}: \mathrm{Al}$ window layer and mechanical scribing to a cell area of $9 \mathrm{~mm}^{2}$.

Transmission electron microscopy (TEM) analysis was performed on a JEOL 2200FS TEM/STEM operated at $200 \mathrm{kV}$. Morphology and composition were analyzed using X-ray fluorescence spectroscopy (XRF) from a rhodium target at $45 \mathrm{kV}$, powder X-ray diffraction (XRD) on a Siemens D5000 diffractometer with Ni-filtered $\mathrm{Cu}-\mathrm{K} \alpha$ radiation, and scanning electron microscopy (SEM) on a Hitachi S-4800. Furthermore, depth profiles were obtained by time-of-flight secondary ion mass spectroscopy (ToF-SIMS) by a TOF.SIMS ${ }^{5}$ from IONTOF using $\mathrm{Bi}^{+}$as the primary ions for the analysis $\left(25 \mathrm{kV}, 1 \mathrm{pA}, 100 \times 100 \mu \mathrm{m}^{2}\right)$ after a twosecond sputter cycle with $\mathrm{O}_{2}{ }^{+}$or $\mathrm{Cs}^{+}$for the analysis of positively or negatively charged ions, respectively $\left(2 \mathrm{kV}, 400 \mathrm{nA}\left(\mathrm{O}_{2}\right) / 120 \mathrm{nA}(\mathrm{Cs}), 300 \times 300 \mu \mathrm{m}^{2}\right)$. The ${ }^{108} \mathrm{Cd}$ signal was cut for sputter times exceeding $1100 \mathrm{~s}$ due to an overlap with MoO. To study the decomposition and $\mathrm{Cu} / \mathrm{In}$ oxidation processes, thermogravimetric (TGA) and differential thermal analysis (DTA) measurements were performed using a Netzsch STA 409 CD thermobalance. The applied temperature program consisted of $5{ }^{\circ} \mathrm{C} / \mathrm{min}$ ramping to $550{ }^{\circ} \mathrm{C}$ under $50 \mathrm{ml} / \mathrm{min}$ flow of synthetic air. Gaseous reaction products were detected from the TGA exhaust flow with Netzsch QMS 403C Aeolos quadrupole mass spectrometer (MS). Inductively coupled plasma mass spectrometry measurements (ICP-MS) were performed with an Agilent 7500cs ICP-MS using Merck ICP-MS single element standards $(0.1-10,000 \mu \mathrm{g} / \mathrm{l})$ for calibration. In-situ XRD was carried out using a PANalytical X'Pert Pro MPD system with Ni-filtered $\mathrm{Cu}-\mathrm{K}_{\alpha}$ radiation in grazing angle geometry at an incident angle of $10^{\circ}$. The substrate heating at $5{ }^{\circ} \mathrm{C} / \mathrm{min}$ under $\mathrm{N}_{2}$ (99.999\%, Messer, Switzerland) atmosphere was done with an Anton-Paar XRK 900 heating chamber. Electron-beam induced current measurements (EBIC) were conducted on mechanically cleaved samples with a FEI Strata DB235 in SEM mode at an acceleration voltage of $2 \mathrm{kV}$. Time-resolved photoluminescence was measured with a nearinfrared compact fluorescence lifetime spectrometer $\mathrm{C} 12132$ by Hamamatsu with an excitation wavelength of $532 \mathrm{~nm}$ and a detection wavelength of $1210 \mathrm{~nm}$, corresponding to the photoluminescence maximum. The system allows lifetime measurements down to $0.2 \mathrm{~ns}$ by using deconvolution. The capacitance for admittance spectroscopy (AS) and C(V) measurements was obtained with an Agilent E4980A LCR meter (Agilent Technologies Inc.) in the frequency range of $200 \mathrm{~Hz}-2 \mathrm{MHz}$ for $\mathrm{AS}$ and fixed at $300 \mathrm{kHz}$ for $\mathrm{C}(\mathrm{V})$ measurements. Temperatures were varied from $120 \mathrm{~K}$ to $300 \mathrm{~K}$ in a cryostat cooled by liquid $\mathrm{N}_{2}$. The 1-D solar cell simulation software SCAPS (v.3.2.01) was used to reproduce C(V) measurements. The "example CIGS.def" file was altered by adjusting d(CIS) $=1 \mu \mathrm{m}, \mathrm{Egap}_{\text {ga }}=$ $1.0 \mathrm{eV}, \mathrm{N}_{\mathrm{A}}$ (shallow) $=0 \mathrm{~cm}^{-3}$ and introducing a single acceptor-type defect $\mathrm{N}_{\mathrm{t}}(250 \mathrm{mV})=$ $3 \times 10^{16} \mathrm{~cm}^{-3} . \mathrm{J}(\mathrm{V})$ measurements were conducted at simulated standard testing conditions $\left(25^{\circ} \mathrm{C}, 1000 \mathrm{~W} / \mathrm{m}^{2}\right.$, AM1.5G illumination). The spectral mismatch was corrected with EQE measurements from a chopped white light source and dual grating monochromator that were calibrated with a certified mc-Si solar cell from Fraunhofer ISE and a Ge-diode from Thorlabs. 


\section{RESULTS AND DISCUSSION}

\subsection{Nanoparticle Ink Precursor}

Two monometallic inks were developed to allow for the stoichiometry control by means of adjusting the individual ink mixing ratios. Particle size and shape, as determined by transmission electron microscopy (TEM) from dried particles, can be seen in Figure 1. While $\mathrm{Cu}$ particles appear elongated and smooth-edged (Figure 1a), a more brittle nature with broader size distribution is apparent for the In- particles (Figure 1b). Ensuring diversity in the size and shape of precursor particles can be a suitable practice for improving packing density and layer adhesion [20,21]. The stability of the particles and thus the inertness to selenization can be influenced by the chemical coordination of the anions. The low enthalpy of formation of oxide particles, for example, necessitates the employment of additional reduction steps or the use of toxic and explosive $\mathrm{H}_{2} \mathrm{Se}$ gas which can lead to undesired segregations of metal alloys and significantly raise the complexity of the process [22,23]. The lower row in Figure 1 illustrates the powder diffraction of precursor particles dried at $80{ }^{\circ} \mathrm{C}$, revealing $\mathrm{Cu}_{2}(\mathrm{OH})_{3}\left(\mathrm{NO}_{3}\right)$ (JCPDS 01-075-1779) and mixed In(OH) (JCPDS 01-073-1810), InOOH (JCPDS 01-071-2283), and $\mathrm{InCl}_{3}$ (JCPDS 01-070-1238) crystalline phases for the $\mathrm{Cu}$ - and Inink, respectively. The mostly hydroxide nature of the particles and hence weaker coordination of the metal cations allows for the complete conversion with elemental selenium [14].

Thermogravimetric analysis (TGA) and differential thermal analysis (DTA) of the respective inks were performed in synthetic air to elucidate the $\mathrm{Cu}$ and $\mathrm{In}$ oxidation and decomposition behavior of the organic components (Figure $2 \mathrm{a}-\mathrm{b}$ ). Simultaneous recording of the mass-spectrometry (MS) data of volatile decomposition products at the thermobalance exhaust, i.e. mass fractions $\mathrm{m} / \mathrm{z}=44\left(\mathrm{CO}_{2}\right.$ or $\left.\mathrm{CH}_{3} \mathrm{CHO}\right)$ and $\mathrm{m} / \mathrm{z}=18\left(\mathrm{H}_{2} \mathrm{O}\right)$, provided additional information for tracing the underlying phase transformations (Figure $2 \mathrm{c}-\mathrm{d}$ ). In agreement with literature, the endothermic evaporation and decomposition of butyl glycol acetate solvent appears at around $190^{\circ} \mathrm{C}\left(\mathrm{bp}=192{ }^{\circ} \mathrm{C}\right)$ [24]. The accompanying MS peaks in both $\mathrm{m} / \mathrm{z}=44$ and 18 represent decomposition products of the solvent. For the $\mathrm{Cu}$ - ink, the exothermal peak at $250{ }^{\circ} \mathrm{C}$ can be attributed to formation of copper oxide under release of $\mathrm{H}_{2} \mathrm{O}$ (Figure 2d-IIa) and NO (not shown) and the decomposition of stabilizer (Figure 2d-IIb). A small exothermal reaction at $300{ }^{\circ} \mathrm{C}$, accompanied by the release of $\mathrm{CO}_{2}$ (Figure 2a, 2cIIIa), can be attributed to the decomposition of further organic species, understood as the coordinated component of the solvent. The In- ink, in contrast, shows a prolonged exothermal reaction from $250{ }^{\circ} \mathrm{C}$ to $450{ }^{\circ} \mathrm{C}$. The continuous release of $\mathrm{CO}_{2}$ and $\mathrm{H}_{2} \mathrm{O}$ during the latter suggests a prolonged decomposition of organics and particles. It is worth noting that indium oxide is formed already at $300{ }^{\circ} \mathrm{C}$ when no organic stabilizer or solvent is used. In the case of both inks, no organic decomposition was found beyond $450{ }^{\circ} \mathrm{C}$, suggesting a complete carbon removal.

\subsection{Liquid phase sintering}

Precursor layers with 5\% Cu- and 20-30\% Se-excess in form of a Se top-coating were prepared on Mo-covered soda lime glass substrates. In-situ XRD measurements in Figure 3a 
depict the occurring phase transitions for the precursor layer during heat ramp-up. The color scale illustrates peak intensities while assigned crystalline phases are indicted in the graph. The Se top layer appears crystalline from $100{ }^{\circ} \mathrm{C}$ until $220^{\circ} \mathrm{C}$ when it begins to melt. At this point, first selenide phases of hexagonal $\alpha$-Cu-Se (klockmannite (KM), JCPDS: 34-0171) can be detected that undergoes a polymorphic transformation to $\gamma$-CuSe (JCPDS: 49-1457) around $270{ }^{\circ} \mathrm{C}$, together with the appearance of orthorhombic CuSe 2 (JCPDS: 19-0400). CuInSe 2 (JCPDS 40-1487) begins to form at $300{ }^{\circ} \mathrm{C}$ together with cubic $\mathrm{Cu}_{2-x} \mathrm{Se}$ (JCPDS 06-0680). The simultaneous decrease in CuSe phase suggests the reaction of $\mathrm{CuSe}+\mathrm{InSe} \rightarrow \mathrm{CuInSe} 2$ or $\mathrm{CuSe}+\mathrm{InSe} \rightarrow 1 / 2 \mathrm{Cu}_{2} \mathrm{Se}+1 / 2 \mathrm{Se}$ (liq.) $+\mathrm{InSe} \rightarrow \mathrm{CuInSe}_{2}$ [25,26]. The formation of detrimental $\mathrm{In}_{2} \mathrm{O}_{3}$ can be seen from $330{ }^{\circ} \mathrm{C}$ onwards, decreasing again at $400{ }^{\circ} \mathrm{C}$ and being completely removed at $450{ }^{\circ} \mathrm{C}$. This is a remarkable finding as no additional reducing atmosphere was employed. In agreement with TGA/DTA measurements showing $\mathrm{CO}_{2}$ evolution at $450{ }^{\circ} \mathrm{C}$ (Figure 2c-IIIb), we suggest the oxidation of organics as a possible reducing mechanism for $\mathrm{In}_{2} \mathrm{O}_{3}$.

Ex-situ measurements were conducted to investigate the sintering behavior. Figure $3 \mathrm{~b}$ depicts the XRF determined total amount of Se as well as the amount of incorporated Se in dependence on temperature. The latter value was obtained by evaporating residual elemental Se by heating the sample to $170{ }^{\circ} \mathrm{C}$ at a pressure of $10^{-4} \mathrm{mbar}$. Through this process, we observed that the stoichiometric Se amount of 50 at.\%, and thus the complete chalcogenization of metals, is already obtained at $\mathrm{T}<350{ }^{\circ} \mathrm{C}$. The thickness of selenized precursor layers from SEM cross-sections $\mathrm{d}_{\mathrm{RTP}}(\mathrm{SEM})$, normalized by the precursor thickness obtained by XRF $\mathrm{d}_{\text {prec }}(\mathrm{XRF})$ [27], however, indicates further densification until $500{ }^{\circ} \mathrm{C}$. The normalization by XRF allows for the decoupling of the actual layer thickness from the amount of $\mathrm{Cu}-\mathrm{In}$-Se material per unit area. Figure 3c depicts the corresponding cross-sections of separate samples from interrupted process steps ranging from $300-500{ }^{\circ} \mathrm{C}$. At $300{ }^{\circ} \mathrm{C}$, melted Se droplets on top of the porous precursor layer are visible. Further increase in temperature increases the wettability of liquid Se and facilitates its penetration into the precursor matrix. In agreement with XRF measurements in Figure 3b, an excess of elemental Se remains visible for temperatures up to $450{ }^{\circ} \mathrm{C}$. Finally, at $500{ }^{\circ} \mathrm{C}$, all excess $\mathrm{Se}$ is evaporated leaving a thick, sintered top crust at the surface.

The influence of liquid Se in terms of densification and grain growth is summarized in Figure 4. Upon melting of Se from $220{ }^{\circ} \mathrm{C}$ onwards, the chalcogenization of the precursor takes place. Until $350{ }^{\circ} \mathrm{C}$ liquid Se has almost fully penetrated the precursor matrix and the majority of chalcogenization reactions are completed. By means of liquid Se, a rearrangement of particles occurs that leads to the observed densification of the precursor layer from 300 $450{ }^{\circ} \mathrm{C}$. Capillary forces and the driving force to minimize the interfacial free energy of the system - in particular $\Delta \mathrm{G}$ (liquid-vapor) - give rise to shear and rotational movements of particles reducing the porosity from loose random packing to the dense close packing. The liquid Se film can thereby act as a lubricant or fluxing agent [28]. For temperatures above $220{ }^{\circ} \mathrm{C}$ a finite amount of $\mathrm{CuInSe}_{2}$ can be soluble in liquid Se [17,29]. Upon evaporation of $\mathrm{Se}$, the solubility of $\mathrm{CuInSe}_{2}$ is reduced and solution- reprecipitation occurs. The generation of 
large crystals is thereby preferred further reducing the interfacial free energy $\Delta \mathrm{G}$ (solid-liquid). This final step, in our case at $500{ }^{\circ} \mathrm{C}$, leads to additional densification and large grain growth at the surface of the layer. The grain size can be further increased through temperature and time promoted solid state sintering.

\subsection{Characterization of $\mathrm{CuInSe}_{2}$ absorber layers}

The capability of liquid-assisted sintering of nanoparticle precursor layers is evident in Figure 5a. The depicted SEM cross-section was taken from a precursor layer selenized with the liquid-selenium-assisted process described above (after the KCN etching treatment). In comparison to films in Figure 3c, the precursor thickness was decreased to avoid the formation of a porous bottom layer. Single grains spanning the complete film thickness of about $1 \mu \mathrm{m}$ can be obtained. Laterally, the grains reached an exceptionally large size of up to $4 \mu \mathrm{m}$ with a smooth shaped curvature. While XRD showed single phase $\mathrm{CuInSe}_{2}$ material, further characterization of elemental distribution was carried out by means of secondary ion mass spectrometry (SIMS). Figure $5 \mathrm{~b}$ shows a smooth $\mathrm{Cu}$ and $\mathrm{In}$ depth profile throughout the absorber with a minor $\mathrm{Cu} / \mathrm{In}$ increase towards the back contact. Furthermore, the amount of Se is homogeneously distributed in the absorber with an increase towards the back contact, which related to the formation of a MoSe 2 layer, as confirmed also by XRD. Despite the TGA results depicting carbon decomposition until $450{ }^{\circ} \mathrm{C}$ (Figure $2 \mathrm{c}$ ), impurity elements such as carbon and oxygen can still be detected by SIMS. While the amount on the surface can be largely attributed to surface contamination, the increase towards the back contact is significant and clearly well above the detection limit.

Admittance spectroscopy measurements were carried out to identify the energetic position of defect levels arising from impurities or growth conditions. From the C(f) data, the defect spectrum in the band gap of the absorber layer was calculated following the method used in Walter et al. [30]. Figure 6a shows two deep defects at 130 and $220 \mathrm{meV}$ with Gaussian integrated defect densities of $4 \times 10^{15} \mathrm{~cm}^{-3}$ and $2 \times 10^{16} \mathrm{~cm}^{-3}$, respectively. While the lower energy defect could be related to the $\mathrm{N} 1$ defect that is typically found in $\mathrm{CI}(\mathrm{G}) \mathrm{S}$ solar cells, the origin of the deeper defect is not fully understood yet [31-33]. A possible source could be the acceptor-type defects from $\mathrm{Cu}_{\mathrm{In}}{ }^{0 /-}(220-320 \mathrm{meV})$ which have negative formation energies at $\mathrm{Cu}$-rich growth conditions $[34,35]$. C(V) measurements at $300 \mathrm{kHz}$ further reveal a freeze-out of the typical capacitance-voltage behavior from room temperature until $120 \mathrm{~K}$ (Figure 6c). This behavior strongly contrasts that of high-efficiency CIGS solar cells, where shallow acceptor-type defects $\mathrm{V}_{\mathrm{Cu}}{ }^{0 /-}(30-45 \mathrm{meV})$ are dominant [34]. Simulations with the 1D program SCAPS were able to reproduce the freeze out behavior by setting $\mathrm{N}_{\mathrm{A}}$ (shallow) to zero and introducing a deep acceptor-type defect with $\mathrm{N}_{\mathrm{A}}(250 \mathrm{mV})=3 \times 10^{16} \mathrm{~cm}^{-3}$ (Figure 6d) [36]. The lifetime was obtained by time-resolved photoluminescence measurements (TR-PL) at the band edge emission $(\mathrm{E}=1.02 \mathrm{eV}$ ) using a single exponential fit (Figure $6 \mathrm{~b}$ ). The short minority carrier lifetime of $0.6 \pm 0.2 \mathrm{~ns}$, which is two orders of magnitude lower than for high efficiency CIGS devices, could be partly related to the large concentration of deep defects in the absorber layer $[4,37,38]$. 
Short minority carrier lifetimes necessitate a good carrier collection to obtain efficient solar cells. This was probed on a micro-scale with electron beam induced current (EBIC) measurements that were superimposed in red on grey-scale SEM pictures (Figure 7a). Similar to observations in the literature for Ga- free absorbers, we found a large carrier collection length extending throughout the entire large-grained part of the absorber layer $[39,40]$. No contribution to the carrier collection, however, is seen for the smaller-grained material. External quantum efficiency (EQE) measurements corroborate this finding of good collection lengths, showing high collection in the long-wavelength region and a flat bias ratio EQE($0.5 \mathrm{~V}) / \mathrm{EQE}(0 \mathrm{~V})$ at unity (Figure $7 \mathrm{~b})$. Devices employing absorber layers from this process exhibited up to $8.00 \%$ efficiency on a total area of $9 \mathrm{~mm}^{2}$ without AR-coating. Compared to CIS cells obtained by PVD, the biggest losses can be attributed to the still low open-circuit voltage of $363 \mathrm{mV}$. This is also in line with temperature dependent $\mathrm{J}_{\mathrm{SC}}-\mathrm{V}_{\mathrm{OC}}$ measurements between 120 and $300 \mathrm{~K}$ that showed an activation energy $E_{a}$ of the reverse saturation current density of $0.8 \mathrm{eV}$ for our devices [41]. Similarly to results from PVD processed Cu-rich absorbers the considerably lower activation energy than the band gap indicates dominant recombination at the interface [42]. The introduction of a Cu-poor stoichiometry, leading to the formation of shallow acceptor-type defects or an ordered defect compound (ODC) phase towards the CdS interface, could remedy this problem $[35,43]$.

\section{CONCLUSION}

Liquid selenium was shown to act as an effective fluxing agent during the sintering of nanoparticle precursor layers below $500{ }^{\circ} \mathrm{C}$. Densification, primarily through the rearrangement of particles and solution- reprecipitation, facilitated up to $1 \mu \mathrm{m}$ thick, dense absorber layers with grains up to $4 \mu \mathrm{m}$ in size. The use of hydroxide based particles with organic stabilizers and solvents enabled the conversion without toxic and/or explosive $\mathrm{H}_{2} / \mathrm{H}_{2} \mathrm{Se}$ gases. TGA results indicate that the decomposition and oxidation of organics can act as a reducing agent to fully convert detrimental $\mathrm{In}_{2} \mathrm{O}_{3}$ phases. Cu-rich growth conditions were used to ensure good wetting of liquid selenium during the growth [17]. The employed growth conditions, however, led to a lack of shallow acceptor-type defects which is believed to be limiting the VOC of solar cells. Despite the short minority carrier lifetimes of $0.6 \mathrm{ns,}$ good carrier collection lengths in CuInSe 2 enabled up to $8.00 \%$ efficient solar cells. Further process optimization and application of an additional $\mathrm{Si}_{3} \mathrm{~N}_{4}$ barrier layer to block sodium diffusion from the substrate facilitated conversion efficiencies up to $8.73 \% \quad\left(V_{O C}=378 \mathrm{mV}\right.$, $\mathrm{FF}=63.9 \%, \mathrm{~J}_{\mathrm{SC}}=36.1 \mathrm{~mA} / \mathrm{cm}^{2}$ ) mainly through improvements in $\mathrm{VOC}$ and $\mathrm{FF}$. To our knowledge, this is the highest efficiency for a $\mathrm{CuInSe} 2$ solar cell obtained by a liquid coating process without hydrazine solvents or utilizing $\mathrm{H}_{2} / \mathrm{H}_{2} \mathrm{Se}$ gases. Comparable cell efficiency values to Cu-rich PVD-deposited absorbers [44] highlight the potential of non-vacuum deposition and liquid-selenium-assisted sintering processes. 


\section{ACKNOWLEDGEMENTS}

This work was conducted in the framework of the European FP7 project "NOVA-CIGS". A.R.U acknowledges the support from the Department of Metal Physics and Technology at ETH. The Laboratory for Electronics/ Metrology/ Reliability at Empa, the Laboratory for Solid State Chemistry and Catalysis at Empa, and Laboratory for Water Resources and Drinking Water at Eawag are acknowledged for facilitating EBIC and SEM, TGA/DTA and in-situ XRD, and ICP-MS measurements, respectively. Hamamatsu (Switzerland) is acknowledged for enabling TR-PL measurements.

\section{REFERENCES}

[1] media release from April $2^{\text {nd }} 2014, \quad$ http://www.solarfrontier.com/eng/news/2014/C031367.html.

[2] Chirila A, Reinhard P, Pianezzi F, Bloesch P, Uhl AR, Fella C, Kranz L, Keller D, Gretener C, Hagendorfer H, Jaeger D, Erni R, Nishiwaki S, Buecheler S, Tiwari AN. Potassium-induced surface modification of $\mathrm{Cu}(\mathrm{In}, \mathrm{Ga}) \mathrm{Se}_{2}$ thin films for high-efficiency solar cells. Nature Materials 2013, 12: 1107-1111.

[3] Brown G, Stone P, Woodruff J, Cardozo B, Jackrel D. Device characteristics of a $17.1 \%$ efficient solar cell deposited by a non-vacuum printing method on flexible foil. $38^{\text {th }}$ IEEE Photovoltaic Specialists Conference 2012, 3230-3233.

[4] Todorov TK, Gunawan O, Gokmen T, Mitzi DB. Solution processed Cu(In,Ga)(S,Se)2 absorber yielding a 15.2\% efficient solar cell. Prog. Photovoltaics 2013, 21: 82-87.

[5] Hahn H, Frank G, Klinger W, Meyer A, Stoerger G. Untersuchungen über ternäre Chalkogenide. V. Über einige ternäre Chalkogenide mit Chalkopyritstruktur. Z. Anorg. Chem. 1953, 271: 153-170.

[6] Mickelsen RA, Chen WS. Development of a 9.4\% efficient thin-film $\mathrm{CuInSe}_{2} / \mathrm{CdS}$ solar cell. Proc. $15^{\text {th }}$ IEEE Photovoltaic Specialists Conference 1981, 800-804.

[7] Hedstrom J, Ohlsen H, Bodegard M, Kylner AMC, Stolt L, Hariskos D, Ruckh M, Schock HW. $\mathrm{ZnO} / \mathrm{CdS} / \mathrm{Cu}(\mathrm{In}, \mathrm{Ga}) \mathrm{Se}_{2}$ thin film solar cells with improved performance. $23^{\text {rd }}$ IEEE Photovoltaic Specialists Conference 1993, 364-371.

[8] AbuSharma JAM, Johnston S, Moriarty T, Teeter G, Ramanathan K, Noufi R. Properties of $\mathrm{ZnO} / \mathrm{CdS} / \mathrm{CuInSe}_{2}$ solar cells with improved performance. Prog. Photovoltaics 2004, 12: 39-45.

[9] Kind C, Feldmann C, Quintilla A, Ahlswede E. Citrate-papped Cu11In9 nanoparticles and its use for thin-film manufacturing of CIS solar cells. Chem. Mater. 2011, 23: 5269-5274.

[10] Liu W, Mitzi DB, Chey SJ, Kellock A. 12\% efficiency CuIn(Se,S $)_{2}$ photovoltaic device prepared using a hydrazine solution process. Mater. Res. Soc. Symp. Proc. 2009, 1123: P06-03-F07-03.

[11] Basol B. Low cost techniques for the preparation of $\mathrm{Cu}(\mathrm{In}, \mathrm{Ga})(\mathrm{Se}, \mathrm{S})_{2}$ absorber layers. Thin Solid Films 2000, 361: 514-519.

[12] Norsworthy G, Leidholm CR, Halani A, Kapur VK, Roe R, Basol BM, Matison R. CIS film growth by metallic ink coating and selenization. Sol. Energ. Mat. Sol. Cells 2000, 60: 127-134. 
[13] Arita T, Suyama N, Kita Y, Kitamura S, Hibino T, Takada H, Omura K, Ueno N, Murozono M. CuInSe 2 films prepared by screen-printing and sintering method. $20^{\text {th }}$ IEEE Photovoltaics Specialists Conference 1988, 1650.

[14] Uhl AR, Koller M, Wallerand AS, Fella CM, Kranz L, Hagendorfer H, Romanyuk YE, Tiwari AN, Yoon S, Weidenkaff A, Friedlmeier TM, Ahlswede E, VanGenechten D, Stassin F. $\mathrm{Cu}(\mathrm{In}, \mathrm{Ga}) \mathrm{Se}_{2}$ absorbers from stacked nanoparticle precursor layers. Thin Solid Films 2013, 535: 138-142, DOI: 10.1016/j.tsf.2012.12.096.

[15] Vervaet A, Burgelmann M, Clemminck I, Capon J. Screen printing of CuInSe 2 films. E.C. Photovoltaic Sol. Energy Conf., Proc. Int. Conf., $9^{\text {th }} 1989,480$.

[16] Vervaet A, Burgelmann M, Clemminck I, Casteleyn M. Screen printing of CIS films for CIS-CdS solar cells. E.C. Photovoltaic Sol. Energy Conf., Proc. Int. Conf., $10^{\text {th }}$ $1991,900$.

[17] Casteleyn M, Burgelmann M, Depuydt B, Clemminck I. Sintering of screen printed CIS layers. E.C. Photovoltaic Sol. Energy Conf., Proc. Int. Conf., $11^{\text {th }} 1992,826$.

[18] Casteleyn M, Burgelmann M, Depuydt B, Niemegeers A, Clemminck I. Growth studies of CuInSe2 using Cu-Se fluxes. 24th IEEE Photovoltaic Specialists Conference 1994, 230.

[19] Hashimoto Y, Kohara N, Negami T, Nishitani M, Wada T. Surface characterization of chemically treated $\mathrm{Cu}(\mathrm{In}, \mathrm{Ga}) \mathrm{Se}_{2}$ thin films. Japanese Journal of Applied Physics Part 1- Regular Papers Short Notes \& Review Papers 1996; 35: 4760-4764.

[20] Sohn HY, Moreland C. The effect of particle size distribution on packing density. Can. J. Chem. Eng. 1968, 46: 162-167.

[21] Masoero E, Del Gado E, Pellenq RJM, Ulm FJ, Yip S. Nanostructure and nanomechanics of cement: polydisperse colloidal packing. Phys. Rev. Lett.2012, 109, 155503.

[22] Guillemoles JF, Kronik L, Cahen D, Rau U, Jasenek A, Schock HW. Stability Issues of Cu(In,Ga)Se2-Based Solar Cells. J. Phys. Chem. B 2000, 104: 4849-4862.

[23] Eberspacher C, Fredric C, Pauls K, Serra J. Thin-film CIS alloy PV materials fabricated using non-vacuum, particles-based technique. Thin Solid Films 2001, 387: 18- 22.

[24] Yaws CL, in Yaws' Critical Data for Chemical Engineers and Chemists, Knovel (http://www.knovel.com) 2012.

[25] Hergert F, Hock R, Weber A, Purwins M, Palm J, Probst V. In situ investigation of the formation of $\mathrm{Cu}(\mathrm{In}, \mathrm{Ga}) \mathrm{Se}_{2}$ from selenized precursors by X-ray diffraction - the impact of Gallium, Sodium, and Selenium excess. J. Phys. Chem. Solids 2005, 66: 1903-1907.

[26] Hergert F, Jost S, Hock R, Purwins M. A crystallographic description of experimentally identified formation reactions of $\mathrm{Cu}(\mathrm{In}, \mathrm{Ga}) \mathrm{Se}$. Solid State Chem. 2006, 179: 2394-2415.

[27] Eisgruber IL, Joshi B, Gomez N, Britt J, Vincent T. In situ X-ray fluorescence used for real-time control of $\mathrm{CuIn}_{\mathrm{x}} \mathrm{Ga}_{1-\mathrm{x}} \mathrm{Se}_{2}$ thin film composition. Thin Solid Films 2002, 408: 64-72.

[28] Kwon OH, in Encyclopedia of Materials- Science and Technology, Vol. 1-11 (Eds. Buschow KHJ, Cahn RW, Merton MC, Ilschner B, Kramer EJ, Mahajan S), Elsevier 2001, Ch. Liquid Phase Sintering: Ceramics. 
[29] Shen J, in Cu-In-Se (Copper-Indium-Selenium) (Eds. Effenberg G, Ilyenko S), SpringerMaterials - $\quad$ The Landolt-Börnstein Database (http://www.springermaterials.com). DOI: 10.1007/10915981 25.

[30] Walter T, Herberholz R, Müller C, Schock HW. Determination of defect distributions from admittance measurements and application to $\mathrm{Cu}(\mathrm{In}, \mathrm{Ga}) \mathrm{Se}_{2}$ based heterojunctions. J. Appl. Phys. 1996, 80:4411-4420.

[31] Herberholz R, Igalson M, Schock HW. Distinction between bulk and interface states in $\mathrm{CuInSe} / \mathrm{CdS} / \mathrm{ZnO}$ by space charge spectroscopy. J. Appl. Phys. 1998, 83:318-325.

[32] Hanna G, Jasenek A, Rau U, Schock HW. Open circuit voltage limitations in $\mathrm{CuIn}_{1-\mathrm{x}} \mathrm{Ga}_{\mathrm{x}} \mathrm{Se}_{2}$ thin-film solar cells. Phys. Status Solidi A 2000, 179:R7-R8.

[33] Cao Q, Gunawan O, Copel M, Reuter KB, Jay Chey S, Deline VR, Mitzi DB. Defects in $\mathrm{Cu}(\mathrm{In}, \mathrm{Ga}) \mathrm{Se}_{2}$ chalcopyrite semiconductors: a comparative study of material properties, defect states, and photovoltaic performance. Adv. Energy Mater., 2011, 1: 845-853.

[34] Moeller HJ, in Handbook of Semiconductor Technology, Vol.1 (Eds. Jackson KA, Schroeter W) Wiley-VCH, Weinheim, Germany 2000, Ch. 12.5.

[35] Zhang S, Wie SH, Zunger A, Katayama-Yoshida H. Defect physics of the CuInSe2 chalcopyrite semiconductor. Phys. Rev. B 1998, 57: 9642.

[36] Burgelman M, Nollet P, Degrave S. Modelling polycrystalline semiconductor solar cells. Thin Solid Films 2000, 361: 527-532.

[37] Ohnesorge B, Weigand R, Bacher G, Forchel A, Riedl W, Karg FH. Minority-carrier lifetime and efficiency of $\mathrm{Cu}(\mathrm{In}, \mathrm{Ga}) \mathrm{Se}_{2}$ solar cells. Appl. Phys. Lett. 1998, 73: 1224.

[38] Metzger WK, Repins IL, Contreras MA. Long lifetimes in high-efficiency $\mathrm{Cu}(\mathrm{In}, \mathrm{Ga}) \mathrm{Se}_{2}$ solar cells. Appl. Phys. Lett.2008, 93: 022110.

[39] Matson RJ, Contreras MA, Tuttle JR, Swartzlander AB, Parilla PA, Noufi R. Effects of the concentration of $\mathrm{Ga}$ on junction formation in thin film $\mathrm{ZnO} / \mathrm{CdS} / \mathrm{CuIn}{ }_{\mathrm{x}} \mathrm{Ga}_{1-\mathrm{x}} \mathrm{Se}_{2} / \mathrm{Mo}$ photovoltaic devices. Mat. Res. Soc. Symp. Proc. 1996, 426: 183.

[40] Nakada T, Kanda Y, Kijima S, Komiya Y, Ohmori D, Ishizaki H, Yamada N. Bifacial CIGS thin film solar cells. Eur. Photovoltaic Sol. Energy Conf., Proc. Int. Conf. 20th 2005, 1736.

[41] Nadenau V, Rau U, Jasenek A, Schock HW. Electronic properties of CuGaSe2- based heterojunction solar cells. Part I. Transport analysis. J. Appl. Phys. 2000, 87: 584-593.

[42] Turcu M, Pakma O, Rau U. Interdependence of absorber composition and recombination mechanism in $\mathrm{Cu}(\mathrm{In}, \mathrm{Ga})(\mathrm{S}, \mathrm{Se})_{2}$ heterojunction solar cells. Appl. Phys. Lett. 2002, 80: 2598.

[43] Siebentritt S, Gütay L, Regesch D, Aida Y, Depredurand V. Why do we make $\mathrm{Cu}(\mathrm{In}, \mathrm{Ga}) \mathrm{Se} 2$ solar cells non-stoichiometric? Sol. Energ. Mat. Sol. Cells 2013, 119: 1825.

[44] Aida Y, Depredurand V, Larsen JK, Arai H, Tanaka D, Kurihara M, Siebentritt S. Curich CuInSe2 solar cells with a Cu-poor surface. Prog. Photovoltaics 2014, DOI: 10.1002/pip.2493. 


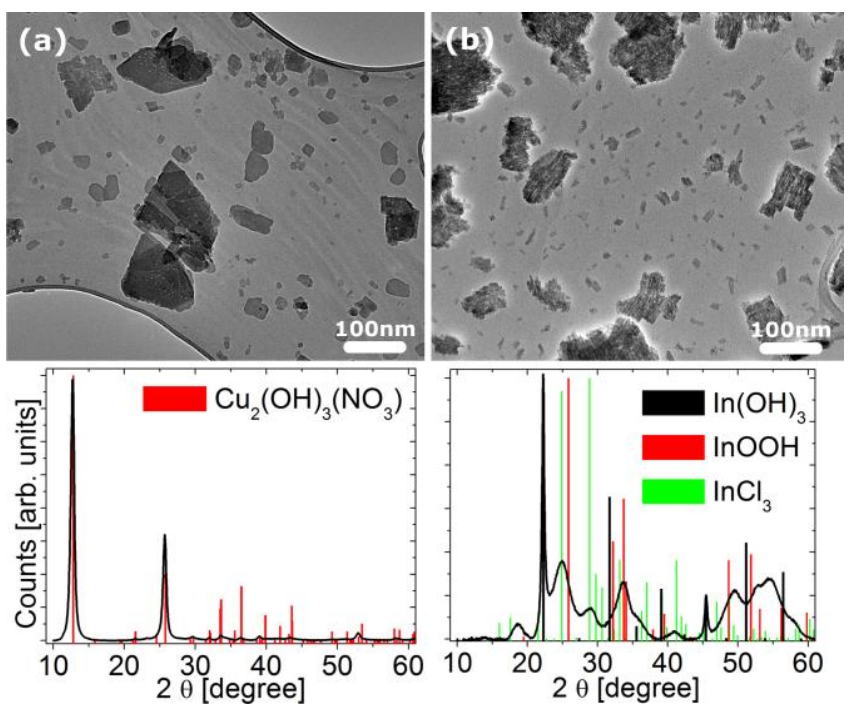

Figure 1. Transmission electron micrographs and XRD patterns of dried nanoparticle precursor inks on a TEM grid. (a) Copper particles were identified as $\mathrm{Cu}_{2}(\mathrm{OH})_{3}\left(\mathrm{NO}_{3}\right)$ while (b) indium particles consist of $\mathrm{In}(\mathrm{OH})_{3}, \mathrm{InOOH}$, and $\mathrm{InCl}_{3}$ multiphase.

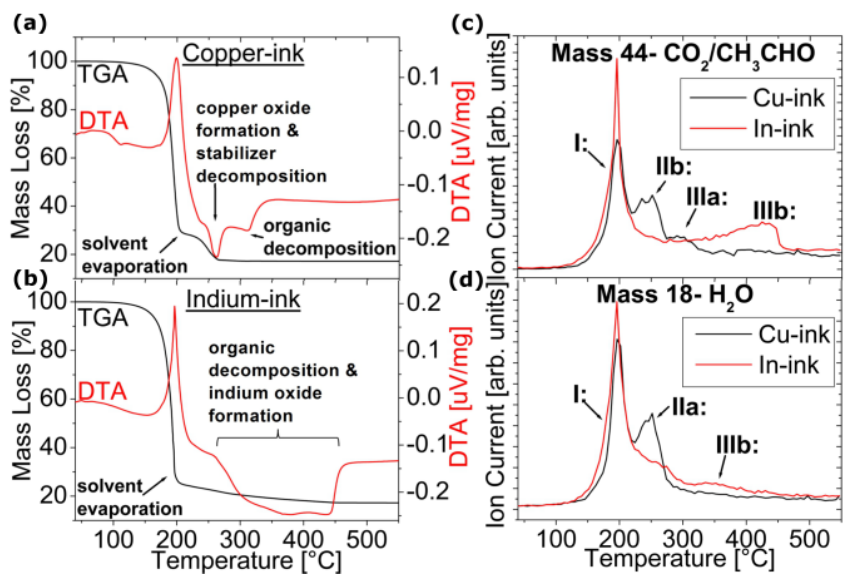

Figure 2. TGA and DTA measurements in synthetic air of the copper- (a) and indium-ink (b), respectively. Together with parallel recorded MS signals $\mathrm{m} / \mathrm{z}=44$ and 18 (c-d), five characteristic regimes can be distinguished: I) solvent evaporation around $190{ }^{\circ} \mathrm{C}$, IIa) $\mathrm{Cu}-$ oxide formation at $250{ }^{\circ} \mathrm{C}$, IIb) stabilizer removal at $250{ }^{\circ} \mathrm{C}$, IIIa) decomposition of the coordinated part of the solvent for $\mathrm{Cu}$-ink, IIIb) decomposition of the coordinated part of the solvent for In- ink and indium oxide formation. 

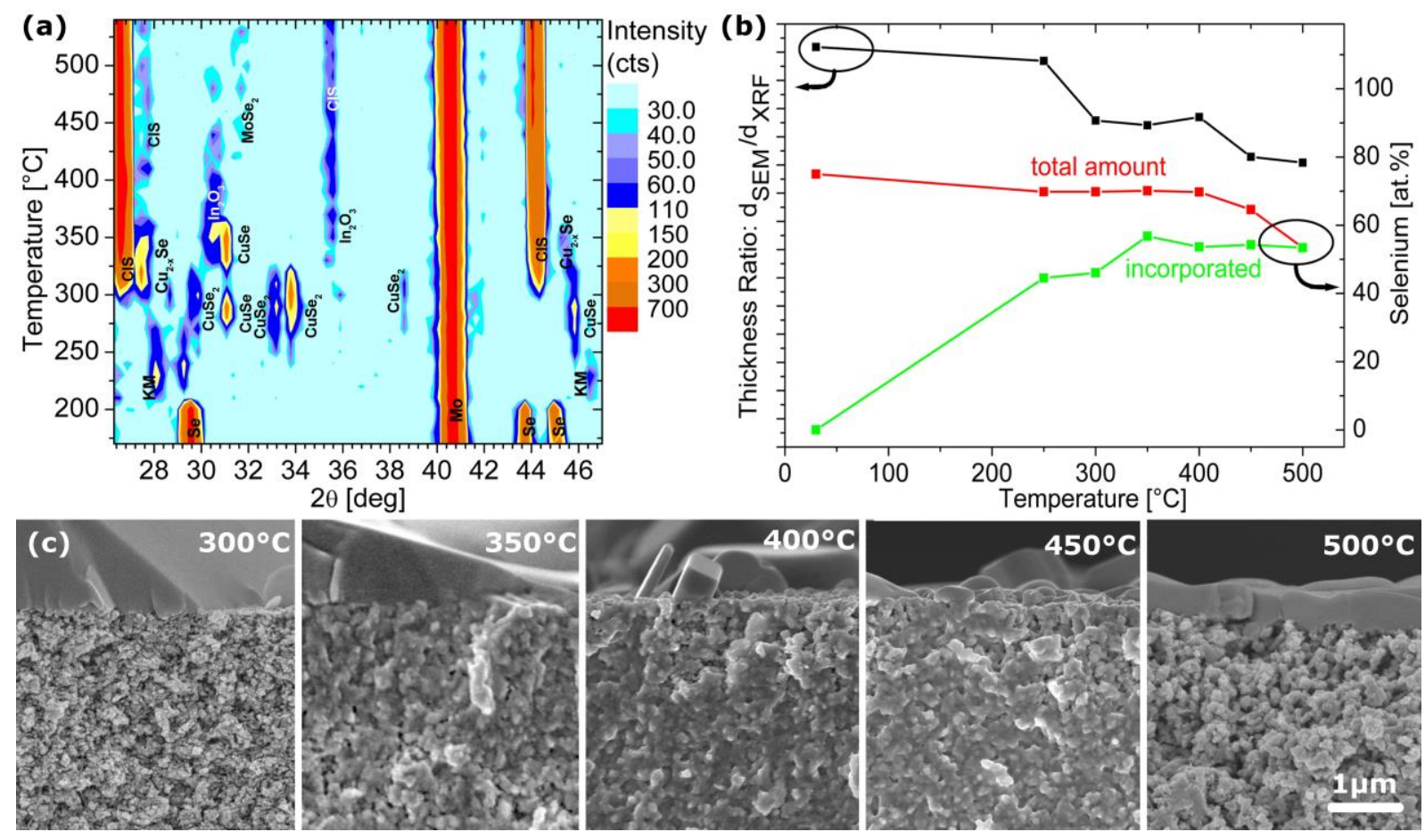

Figure 3. (a) In-situ recording of XRD patterns of a selenium-covered precursor layer during heating from 150 to $550{ }^{\circ} \mathrm{C}$. Selenium melting at $220^{\circ} \mathrm{C}$ is followed by the formation $\mathrm{Cu}-\mathrm{Se}$ phases that react to $\mathrm{CuInSe} 2$ starting at $300{ }^{\circ} \mathrm{C}$. Detrimental $\mathrm{In}_{2} \mathrm{O}_{3}$ at $330{ }^{\circ} \mathrm{C}$ is completely removed at $450{ }^{\circ} \mathrm{C}$. (b) Thickness ratio $\mathrm{d}_{\mathrm{RTP}}(\mathrm{SEM}) / \mathrm{d}_{\text {prec }}(\mathrm{XRF})$, i.e. thickness of selenized precursor layers from SEM cross-sections normalized by the precursor thickness obtained by $\mathrm{XRF}$, as a measure of layer densification during the heat ramp- up. Total and incorporated Se amounts, i.e. amount after removal of residual Se, were determined by means of XRF. (c) SEM cross-sections at interrupted process steps at $300{ }^{\circ} \mathrm{C}$ and $350{ }^{\circ} \mathrm{C}$ show the melted Se and its penetration into the precursor layer, respectively. Upon evaporation of Se at $500{ }^{\circ} \mathrm{C}$, grain growth and the starting formation of a highly sintered top-crust can be observed.

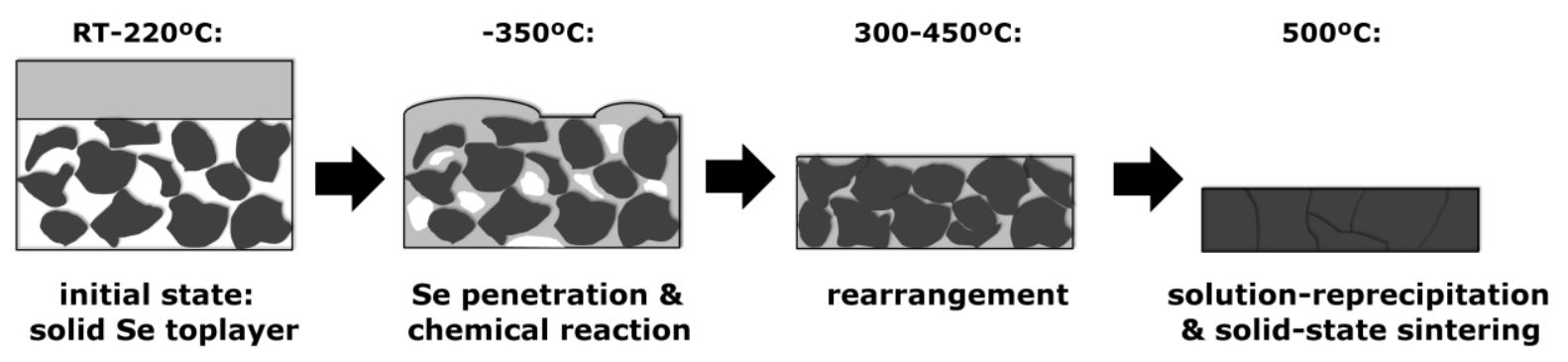

Figure 4. Schematic diagram of liquid-assisted grain growth of $\mathrm{CuInSe}_{2}$ absorber layers. Molten selenium can penetrate the hydrophobic nanoparticle precursor layer upon temperature increase to $350{ }^{\circ} \mathrm{C}$. The precursor reacts with chalcogen to reach the stoichiometric amount of Se. From $300-450{ }^{\circ} \mathrm{C}$, capillary forces cause a rearrangement of particles leading to a densification of the film. Upon evaporation of Se around $500{ }^{\circ} \mathrm{C}$, large grain growth is apparent due to the solution- reprecipitation of dissolved chalcogenide phases accompanied by solid state sintering. 

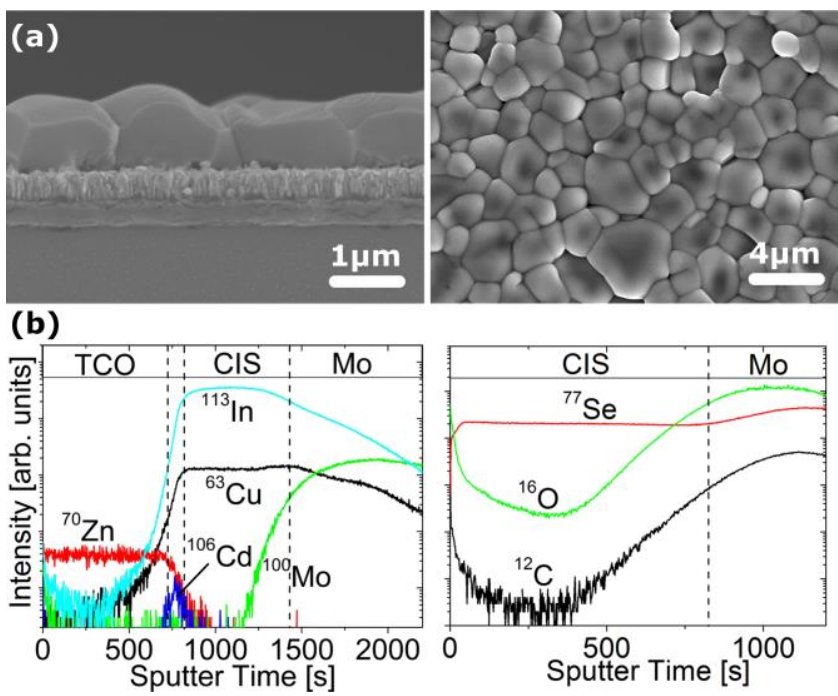

Figure 5. (a) Scanning electron micrographs of selenized precursor layers on Mo/SLG substrate after $\mathrm{KCN}$ etching. A completely sintered absorber layer of $1 \mu \mathrm{m}$ thickness and lateral grain sizes up to $4 \mu \mathrm{m}$ can be obtained by reducing the precursor layer thickness. (b) SIMS compositional depth profiles of completed cell detecting positive ions (left) and CIS/Mo stack detecting negative ions (right). The Se profile appears homogeneous while some impurities from carbon and oxygen tend to accumulate towards the back contact.
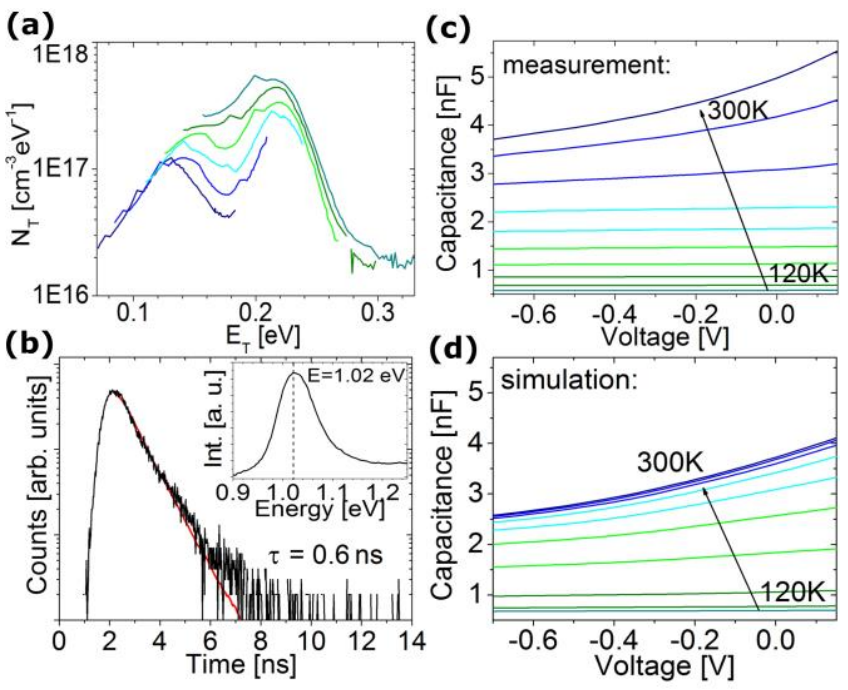

Figure 6. (a) Defect spectra derived from admittance spectra between 140 - 240 K. (b) Timeresolved photoluminescence of a finished solar cell determines a low minority carrier lifetime of $0.6 \pm 0.2 \mathrm{~ns}$. The emission energy of $1.02 \mathrm{eV}$ (see inset) confirms the band gap of CuInSe2. (c) $\mathrm{C}(\mathrm{V})$ measurements show carrier freeze-out for low temperatures. (d) C(V) simulations in SCAPS can reproduce this trend with $\mathrm{N}_{\mathrm{A}}$ (shallow) $=0 \mathrm{~cm}^{-3}$ and $\mathrm{N}_{\mathrm{A}}(250 \mathrm{mV})=3 \cdot 10^{16} \mathrm{~cm}^{-3}$. 

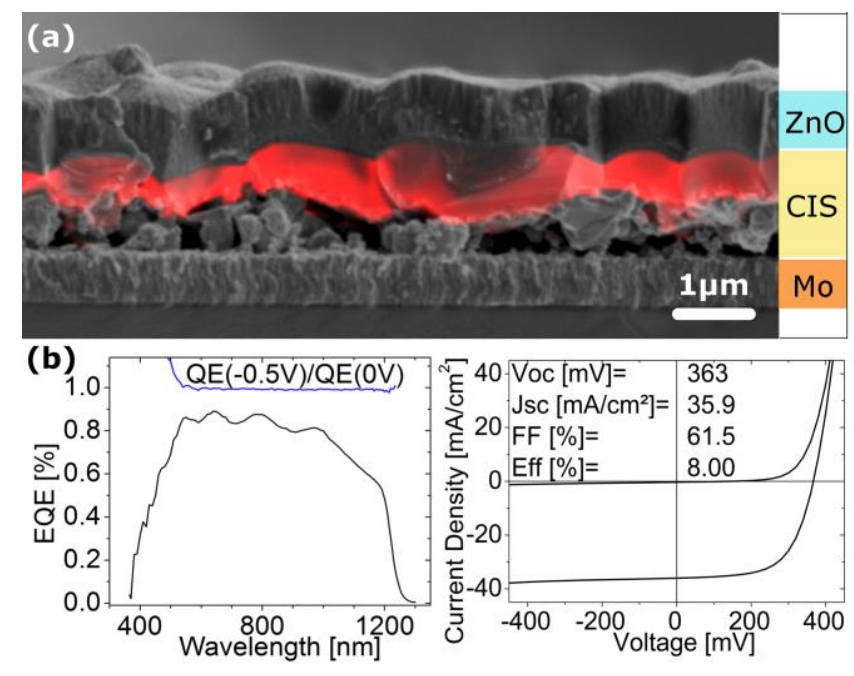

Figure 7. (a) Electron-beam induced current measurements on a cross-section of a $>7 \%$

efficient device (red colored overlay on SEM image). Carriers generated throughout the largegrained material are collected, whereas no collection is indicated for the small-grained bottom layer. (b) External quantum efficiency and its bias ratio EQE(-0.5V)/EQE(0V) confirms good carrier collection efficiency. $\mathrm{J}(\mathrm{V})$ measurements display up to $8.00 \%$ efficiency for a solar cell with printed $\mathrm{CuInSe} 2$ absorber layer (total area, without AR-coating). 